\title{
Peningkatan Literasi Informasi dan Minat Baca Melalui Pelatihan Penelusuran E-Journal dan E-Book di Perpustakaan UPN Veteran Yogyakarta
}

\author{
Nurul Alifah Rahmawati' Luluk Faudah ${ }^{2}$ Bugel Suryanta $^{3}$ \\ 1,2,3 UPT Perpustakaan UPN “Veteran” Yogyakarta \\ email: nurulalifah@upnyk.ac.id
}

\begin{abstract}
Abstrak
Literasi informasi dan minat baca di Indonesia masih signifikan bahkan terdapat survei yang menunjukkan masih tergolong rendah. Salah satu upaya peningkatan yang dapat dilakukan oleh perpustakaan yaitu melalui pelatihan penelusuran sumber-sumber informasi. Pelatihan penelusuran sumber informasi yang dilakukan perpustakaan UPN Veteran Yogyakarta berupa penelusuran jurnal ebsco dan ebook kubuku terhadap mahasiswa magister dan doctor yang terdiri dari 50 peserta. Hal ini dilakukan karena banyaknya mahasiswa yang belum mengetahui dan belum pernah mengakses koleksi digital di perpustakaan, yaitu sebanyak 59,5\%. Kegiatan pelatihan ini dinilai sangat efektif sebesar $73,8 \%$ untuk memperkenalkan koleksi yang dimiliki perpustakaan beserta dengan cara mendapatkan atau mengakses koleksi tersebut. Hasil ini membuat mahasiswa lebih tertarik untuk mengakses koleksi digital yang ada di perpustakaan. Peserta juga mengakui dengan adanya pelatihan ini sangat membantu dalam mengerjakan tugas akhir maupun pembuatan publikasi ilmiah. Sebanyak $69 \%$ dari survei menyatakan bahwa pelatihan yang diadakan oleh perpustakaan UPN Veteran Yogyakarta sangat membantu. Peserta juga menunjukkan minat yang tinggi sebanyak $64,3 \%$ untuk lebih sering mengakses koleksi digital setelah mengikuti pelatihan
\end{abstract}

Kata Kunci:

Literasi Informasi Minat

Baca Pelatihan

\section{A. PENDAHULUAN}

Perkembangan Teknologi Informasi menuntut perubahan-perubahan perpustakaan konvensional menjadi perpustakaan modern ataupun perpustakaan digital. Tidak hanya tata kelola perpustakaannya, tetapi perubahan juga terjadi pada koleksi yang dimiliki. Dengan demikian terjadi alih media atau alih format koleksi dari cetak menjadi digital. Sumber-sumber informasi berkembang dari koleksi buku tercetak menjadi buku elektronik atau sering disebut e-book. Sumber informasi tersebut juga tidak hanya berada di dalam perpustakaan, melainkan tersebar di dunia maya dan dapat diakses kapanpun dan dimanapun. Perpustakaan harus terus mengikuti perkembangan tersebut sebagai wujud eksistensinya menyediakan sumber informasi terkini demi memenuhi kebutuhan pemustaka. Perpustakaan terus mencari upaya untuk meningkatkan minat baca dan literasi informasi bagi pemustaka dengan tantangan beragamnya sumber informasi di dunia maya. Mengingat bahwa minat baca di Indonesia ini masih rendah dan banyak masyarakat yang terjebak dalam informasi palsu atau hoax.

Perpustakaan harus mampu menyediakan sumber informasi ilmiah yang dapat dipertanggungjawabkan kebenarannya di zaman yang milenial ini. Salah satu usaha yang dapat dilakukan untuk meningkatkan literasi informasi dan minat baca yaitu mengadakan pelatihan 
penelusuran sumber-sumber informasi baik tercetak maupun elektronik. Penelusuran sumber-sumber elektronik seperti ebook dan e journal penting untuk dilakukan kepada pemustaka milenial. Pelatihan penelusuran ini dilakukan dengan tujuan untuk memperkenalkan sumber-sumber informasi digital agar pemustaka bias mendapatkan informasi ilmiah dan terhindar dari hoax. Selain itu pelatihan penelusuran sumber-sumber informasi juga dilakukan agar pemustaka terhindar dari perilaku plagiarisme atau menjiplak karya orang lain karena ketidaktahuannya mengenai sumber-sumber informasi yang ada. Dengan adanya pelatihan penelusuran sumber informasi ini dapat menarik perhatian pemustaka terhadap koleksi-koleksi digital, sehingga diharapkan minat baca akan bertambah dan pemustaka lebih terampil untuk memilih sumber-sumber informasi yang ada serta memiliki kemampuan literasi informasi yang lebih baik.

\section{B. KAJIAN TEORITIS}

\section{Literasi Informasi di Perguruan Tinggi}

Literasi informasi sebagai kemampuan mencari, menggunakan dan mengevaluasi infomasi yang dibutuhkan bukanlah keterampilan yang baru muncul di era informasi. Pandangan dan pemahaman terhadap konsep ini terus berkembang seiring dengan perkembangan teknologi informasi dan komunikasi. Namun deskripsi yang paling luas diterima adalah pandangan bahwa literasi informasi merupakan suatu kombinasi antara keahlian, sikap dan pengetahuan dalam mencari informasi (Wahyudi, 2013).

Kemampuan civitas akademik di perguruan tinggi untuk melakukan penelusuran informasi sangat diperlukan. Apalagi informasi yang tersedia saat ini sangat beragam dan selalu berkembang. Keberagaman jenis informasi dalam berbagai format menambah daftar panjang kemampuan penggunaan dan pemanfaatan informasi
(Proboyekti, 2015). Kemampuan ini tidak berhenti sampai penelusuran informasinya saja, melainkan harus mampu menggunakan atau memanfaatkan hingga mengevaluasi informasi yang didapatkan.

\section{Tingkat Minat baca}

Sinambela dalam Batubara (2014) mengatakan bahwa minat membaca merupakan sikap positif seperti ketertarikan yang muncul dalam diri seseorang terhadap aktivitas membaca dan bahan bacaan. Minat memiliki kecenderungan yang menetap untuk memperhatikan beberapa aktivitas. Seseorang yang memiliki minat terhadap sesuatu, maka ia akan memperhatikan dan merasa senang dengan hal tersebut. Minat membaca berarti seseorang memiliki rasa ketertarikan dengan memperhatikan dan senang dengan hal membaca.

\section{Teori Evaluasi Pelatihan}

Kirkpatrick dalam Utomo \& Tehupeiory (2014) mengatakan bahwa evaluasi pelatihan merupakan usaha pengumpulan informasi secara sistematis untuk mengukur hasil pelatihan berdasarkan informasi tersebut. Salah satu model evaluasi pelatihan yang bisanya digunakan adalah metode Kirkpatrick yang mengidentifikasi empat level untuk melakukan evaluasi, yaitu:

Level 1 : Reaksi

Mengukur tingkat kepuasan peserta pelatihan terhadap pelaksanaan pelatihan yang dilakukan. Pada evaluasi level satu ini keberhasilan pelatihan dapat dilihat dari reaksi atau respon peserta pelatihan. Ketertarikan peserta dalam mengikuti pelatihan dan keaktifannya membuat peserta mengikuti pelatihan dengan semangat dan memiliki antusias yang tinggi.

Level 2 : Pembelajaran

Evaluasi level dua mengukur apakah peserta dapat memperhatikan materi yang diberikan oleh 
instruktur atau pemateri. Efektifitas pelatihan dapat diketahui dari dampaknya terhadap peserta.

Level 3 : Perilaku

Pada level ini, evaluasi dilakukan untuk mengetahui apakah pengetahuan yang diperolah saat pelatihan benar-benar dimanfaatkan dalam perilaku sehari-hari. Evaluasi ini disebut sebagai evaluasi terhadap outcomes pelatihan.

Level 4 : Hasil

Hasil akhir dapat berupa indikator-indikator kinerja nyata seperti produktivitas, peningkatan kualitas dan lain-lain.

\section{METODE PENELITIAN}

Metode penelitian yang dilakukan yaitu dengan memberikan pelatihan kepada mahasiswa magister dan doktor dari berbagai fakultas di UPN Veteran Yogyakarta. Materi yang disampaikan berupa pelatihan penelusuran jurnal ebsco dan ebook kubuku. Adapun evaluasi kegiatan penelitian dilakukan melalui kuesioner. Kuesioner berisi beberapa pertanyaan untuk mengetahui apakah setelah mengikuti pelatihan ini menunjukkan keinginan untuk dapat meningkatkan literasi informasi dan minat baca melalui penelusuran jurnal dan ebook di perpustakaan.

\section{HASIL DAN PEMBAHASAN}

Peningkatan kemampuan literasi informasi dan minat baca

Perkembangan teknologi informasi membuat perubahan-perubahan paradigma termasuk di perpustakaan. Salah satunya perubahan sumbersumber informasi dari format tercetak menjadi digital atau elektronik. Untuk melakukan pencarian sumber informasi tersebut dibutuhkan kemampuan literasi yang baik agar informasi dapat ditemukan dengan tepat, efektif dan efisien. Termasuk untuk melakukan pencarian terhadap sumber-sumber digital atau elektronik. Oleh karena itu, kemampuan literasi informasi digital sangat diperlukan.

Salah satu upaya perpustakaan untuk meningkatkan kemampuan literasi informasi bagi pemustaka yaitu dengan mengadakan pelatihan penelusuran sumber informasi e-book dan jurnal. Pelatihan yang telah dilakukan perpustakaan UPN Veteran Yogyakarta salah satunya ditujukan kepada mahasiswa Magister dan Doktoral. Untuk membuat tugas akhir dalam hal ini tesis maupun disertasi, pastinya membutuhkan sumber-sumber informasi yang lebih luas dan lengkap. Oleh karena itu pelatihan penelusuran sumber informasi jurnal maupun e-book penting untuk dilakukan.

Tersedianya sumber informasi digital, khususnya e-book dan e-jurnal memudahkan pemustaka untuk mendapatkan koleksi yang dibutuhkan. Selain format digital yang mudah digunakan, kegiatan membaca dalam format digital juga mulai berkembang, dimana dalam implementasinya kegiatan membaca tersebut mempengaruhi perilaku-perilaku membaca digital didalamnya (Prawesti, 2018). Sehingga, hal ini dapat membuat pemustaka lebih tertarik untuk mengakses koleksi digital di perpustakaan. Koleksi tersebut dapat diakses dimanapun dan kapanpun berada, tidak perlu datang langsung ke perpustakaan.

Pengadaan pelatihan penelusuran sumber informasi berupa e-book dan e-jurnal ini didasari dengan adanya data ringkasan aktivitas mengenai jumlah pembaca, pengunjung maupun konten yang dibaca dalam suatu aplikasi perpustakan digital. Ringkasan tersebut menunjukkan jumlah aktivitas yang sangat sedikit dilakukan oleh pemustaka baik dosen maupun mahasiswa. Hal ini ternyata terbukti berdasarkan survei bahwa pemustaka lebih banyak yang belum pernah mengakses koleksi digital di perpustakaan, yaitu sebanyak $59,5 \%$. Oleh karena itu pelatihan maupun perkenalan terhadap koleksikoleksi perpustakaan harus lebih sering diadakan. 
Diagram survei dapat dilihat sebagai berikut.

Saya sudah pernah mengakses koleksi digital di perpustakaan UPNVY 42 tanggapan

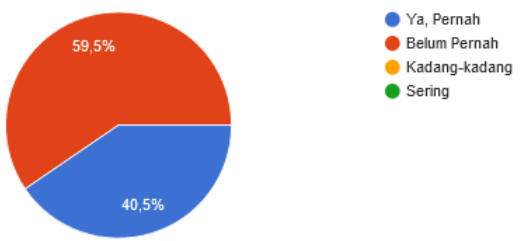

Sumber : Data primer

Berdasarkan survei yang dilakukan setelah diadakan pelatihan penelusuran sumber informasi, menunjukkan bahwa mahasiswa sangat setuju sebesar 73,8\% bahwa dengan adanya koleksi digital, khususnya e-book dan e-journal membuat mereka lebih tertarik untuk mengakses koleksi yang ada di perpustakaan. Sedangkan sebanyak $26,2 \%$ dari 42 tanggapan menyatakan setuju bahwa mereka lebih tertarik untuk mengakses koleksi dengan tersedianya koleksi digital di perpustakaan. Hal ini menunjukkan bahwa seiring berkembangnya teknologi, berkembangnya koleksi menjadi digital juga mempengaruhi ketertarikan pemustaka untuk mengaksesnya. Hal ini secara tidak langsung dapat meningkatkan minat baca pemustaka secara signifikan, karena minat muncul dari suatu ketertarikan

Tersedianya koleksi digital, khususnya e book dan e journal membuat saya lebih tertarik mengakses koleksi Perpustakaan UPNVY 42 tanggapan

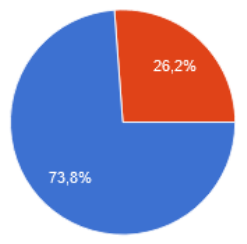

- Sangat Setuju

Setuju

Tidak Setuju

- Sangat Tidak Setuju

Sumber : Data Primer

Gambar 1:Tersedianya koleksi digital, membuat pemustaka lebih tertarik mengakses

Tujuan lain dari pelatihan penelusuran sumber informasi atau koleksi digital berupa ebook dan ejurnal selain untuk meningkatkan literasi bagi pemustakanya, juga bertujuan untuk mengenalkan koleksi-koleksi ataupun sumber informasi baik yang berada didalam perpustakaan ataupun diluar perpustakaan. Artinya, tidak hanya koleksi yang berada di dalam perpustakaan, tetapi koleksi yang dimiliki oleh instansi yang lainnya, bahkan koleksi berupa database dari luar yang dilanggan oleh perpustakaan.

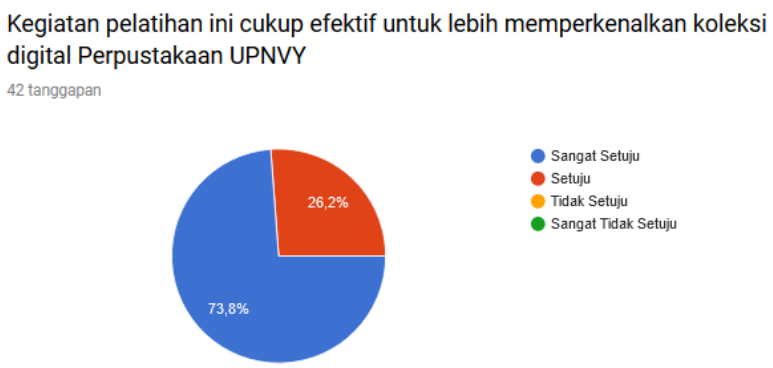

Sumber : Data Primer

Kegiatan pelatihan ini dinilai sangat efektif sebesar 73,8\% untuk memperkenalkan koleksi yang dimiliki perpustakaan beserta dengan cara mendapatkan atau mengakses koleksi tersebut. Selain itu kegiatan pelatihan penelusuran sumber informasi ini juga dinilai sangat membantu mahasiswa dalam mengakses sumber informasi yang digunakan dalam pembuatan tugas akhir maupun publikasi ilmiah. Hal ini mengingat bahwa mahasiswa magister dan doctoral biasanya diwajibkan untuk menerbitkan publikasi ilmiah di salah satu jurnal sebagai syarat kelulusannya. Oleh karena itu sumber-sumber informasi terkini sangat dibutuhkan. Sebanyak 69\% dari survei menyatakan bahwa pelatihan yang diadakan oleh perpustakaan UPN Veteran Yogyakarta sangat membantu. Adapun diagramnya sebagai berikut. 
Kegiatan Pelatihan ini sangat membantu saya untuk dapat mengakses sumber informasi dalam menunjang pembuatan Tugas Akhir dan Publikasi Ilmiah

42 tanggapan

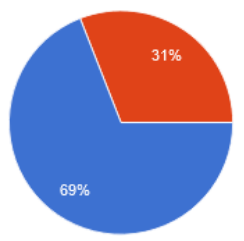

- Sangat Setuju

- Setuju

- Tidak Setuju

- Sangat Tidak Setuju

Sumber : data primer

Hasil dari suatu pelatihan salah satunya mengukur tingkat kepuasan dan mengetahui apakah terjadi peningkatan atau ketertarikan terhadap sesuatu yang telah dilakukan. Berdasarkan survei, mahasiswa sangat setuju bahwa mereka akan lebih sering untuk mengakses koleksi digital di perpustakaan UPN Veteran Yogyakarta setelah mengikuti pelatihan. Ketertarikan ini diharapkan akan terus meningkatkan minat baca mahasiswa sehingga menciptakan generasi milenial yang literat.

Setelah mengikuti pelatihan ini, saya akan lebih sering mengakses koleksi digital di Perpustakaan UPNVY

42 tanggapan

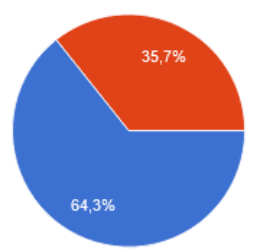

Sangat Tidak Setuju

Sumber : data primer

Berdasarkan diagram diatas terdapat ketertarikan peserta untuk mengakses koleksi digital di perpustakaan yaitu sebesar 64,3\%. Ketertarikan tersebut diakui setelah mengikuti pelatihan dan mengetahui cara mengakses koleksi digital jurnal dan ebook di perpustakaan. Peserta juga menunjukkan minat yang tinggi untuk mengikuti pelatihan lagi. Hal ini dapat dilihat dari beberapa masukan yang diberikan sebagai berikut,

"Pelatihan seperti ini terus dilanjutkan sesuai dengan industry 4.0" (Januario Pereira sebagai peserta pelatihan dari jurusan Magister Manajemen Bencana)

"Pelatihan seperti ini terus dilanjutkan" (Tania Ayu Apsari sebagai peserta pelatihan dari jurusan Magister Ilmu Komunikasi)

Berdasarkan pernyataan diatas, reaksi maupun respon peserta terhadap pelatihan menunjukkan minat dan antusias yang baik. Hal ini dapat menjadi indikasi bahwa peserta akan meningkatkan literasi informasi dan minat membaca dengan memanfaatkan jurnal-jurnal serta koleksi buku yang ada di perpustakaan.

\section{E. PENUTUP}

Salah satu upaya peningkatan literasi informasi dan minat baca yang dapat dilakukan oleh perpustakaan yaitu melalui pelatihan penelusuran sumber-sumber informasi. Pelatihan penelusuran sumber informasi yang dilakukan perpustakaan UPN Veteran Yogyakarta berupa penelusuran jurnal ebsco dan ebook kubuku. Hal ini dilakukan karena banyaknya mahasiswa yang belum mengetahui dan belum pernah mengakses koleksi digital di perpustakaan, yaitu sebanyak 59,5\%. Kegiatan pelatihan ini dinilai sangat efektif sebesar $73,8 \%$ untuk memperkenalkan koleksi yang dimiliki perpustakaan beserta dengan cara mendapatkan atau mengakses koleksi tersebut. Hasil ini membuat mahasiswa lebih tertarik untuk mengakses koleksi digital yang ada di perpustakaan. Peserta juga mengakui dengan adanya pelatihan ini sangat membantu dalam mengerjakan tugas akhir maupun pembuatan publikasi ilmiah. Sebanyak 69\% dari survei menyatakan bahwa pelatihan yang diadakan oleh perpustakaan UPN Veteran Yogyakarta sangat membantu. Peserta juga menunjukkan minat yang tinggi untuk mengikuti pelatihan lagi. Dengan demikian pelatihan penelusuran sumber informasi yang dilakukan dapat menjadikan generasi milenial khususnya mahasiswa UPN Veteran Yogyakarta 
menjadi generasi yang literat dan mempunyai minat baca yang tinggi untuk menghindari perilaku yang tidak baik termasuk hoax.

\section{DAFTAR PUSTAKA}

Batubara, A. M. (2014). Minat mahasiswa membaca (Study di Fakultas IImu Sosial dan IImu Politik Universitas Riau Pekanbaru). Jurnal Online Mahasiswa Fakultas IImu Sosial Dan IImu Politik Universitas Riau, 1(2), 1-15.

Prawesti, D. A. (2018). Pengaruh Penggunaan Aplikasi Bacaan Digital Terhadap Tingkat Minat Baca di Kalangan Mahasiswa Universitas Airlangga (Universitas Airlangga). Retrieved from http:// repository.unair.ac.id/72398/3/JURNAL_Fis. IIP.26 18 Pra p.pdf

Proboyekti, U. (2015). Program Literasi informasi di perguruan tinggi. Dipresentasikan Pada Workshop Pengembangan Program Literasi Informasi Bagi Mahasiswa, 11. Retrieved from http://lib.ugm.ac.id/download/materi kegiatan/2015/workshop literasi informasi 2015/Program Literasi Informasi Perguruan Tinggi.pdf

Utomo, A. P., \& Tehupeiory, K. P. (2014). Evaluasi pelatihan dengan metode Kirkpatrick analysis. Jurnal Telematika, 9(2), 37-41.

Wahyudi, P. I. H. (2013). Studi komparatif pentingnya literasi informasi bagi mahasiswa, Visi Pustaka, Vo.15 No.2 Agustus 2013.pdf. Visi Pustaka, 15(2), 80-88. 